Original Article

\title{
ANTIFUNGAL ACTIVITY OF CYANOTIS AXILLARIS (L.) D. DON EX SWEET AGAINST OPPORTUNISTIC FUNGAL STRAINS
}

\author{
ANTO SUGANYA REGIS, JEYA JOTHI GABRIEL \\ Department of Plant Biology and Biotechnology, Loyola College, Nungambakkam, Chennai, Tamil Nadu, India \\ Email: gjjothiloyola@gmail.com
}

Received: 03 Apr 2017 Revised and Accepted: 27 May 2017

\begin{abstract}
Objective: The main focus of the study was to compare and determine the antifungal activities of different solvent extracts of Cyanotis axillaris.

Methods: The dried whole plant of $C$. axillaris was extracted by sequential extraction method using solvents hexane, ethyl acetate and methanol based on their polarity. The antifungal activity of the extracts was tested against 12 opportunistic fungal strains by disc diffusion method. Minimum inhibitory concentration (MIC) was determined using microtiter plate method.

Results: The hexane, ethyl acetate and methanol extracts showed significant antifungal activities. The highest antifungal activity was recorded for ethyl acetate extract of $C$. axillaris. In disc diffusion method at high concentration $(5 \mathrm{mg} / \mathrm{ml})$, the ethyl acetate extract exhibited the zone of inhibition $>30 \mathrm{~mm}$ against $C$. krusei, mentagrophytes, Scopulariopsis sp. and B. cinerea. In MIC the ethyl acetate extract inhibited the growth of $T$. mentagrophytes, Scopulariopsis sp., B. cinerea in its low dose $(0.031 \mathrm{mg} / \mathrm{ml})$. The hexane, ethyl acetate and methanol extracts of $C$. axillaris did not show activity against M. gypseum, T. rubrum and E. floccosum.
\end{abstract}

Conclusion: This is the first report for the antifungal efficacy of $C$. axillaris. The results proved that the extracts of $C$. axillaris have high potential antifungal principles which could fight against the opportunistic and multidrug resistant fungal strains.

Keywords: Antifungal, Cyanotis axillaris, Disc Diffusion, MIC

(C) 2017 The Authors. Published by Innovare Academic Sciences Pvt Ltd. This is an open access article under the CC BY license (http://creativecommons.org/licenses/by/4.0/) DOI: http://dx.doi.org/10.22159/ijpps.2017v9i7.18868

\section{INTRODUCTION}

Fungi are widespread in the environment. Some seen in the normal commensal of animals and humans. During infection, they alter the host immune system and turn as pathogenic, opportunistic and lifethreatening [1]. It is estimated that nearly 300 million people are affected worldwide with serious fungal infections and 25 million are at high risk of dying or losing their sight. The severity of fungal infection in susceptible population ranges from acute, severe to chronic [2-7]. Azoles are the most widely used drugs to treat fungal infections due to their bioavailability and safety profile. Even though it shows a positive response to patients, due to its fungi static effect rather than fungicidal effect frequent relapses occur [8]. Continuous and prolonged treatment with these drugs to an immunocompromised person resulted in the development of multidrug resistant fungal strains [9]. Moreover, prolonged antifungal therapy in heavily immunocompromised people can lead infectionrelated toxicities, nephrotoxicity, hepatotoxicity, recurrent drug infections, organ dysfunction, cutaneous reactions and malignancies [10and11]. For example, oral itraconazole causes nausea, hypertension, hypokalemia, edema in old age people. Therefore it is restricted to patients with heart failure [12]. Voriconazole treatment in ambulatory patients cause phototoxic reactions and this can lead to the development of squamous cell carcinoma and melanoma [13and14]. Increase in the multidrug resistant fungal strains, lack of drugs with new antifungal targets and the adverse effects of antifungal drugs for a long term use urge the need for the new antifungal agents which have new target site or mechanism to fight against multidrugresistant (MDR) fungal strains as well as to overcome the disadvantage of commercially used antifungal drugs.

Cyanotis axillaris is an herbal weed belongs to the family of Commelinaceae. Traditionally C. axillaris is used to treat tympanitis, ascites, abscesses, fever, worms and ear drum infection [15]. There is no data for its antifungal activity in traditional use. Moreover, there is no scientific evidence for its antifungal activity. Since Products from plants are safe, easily available, less expensive, efficient over the synthetic drugs used in the market and having less side effect, we chose C. axillaris to examine its antifungal activity to explore new antifungal bioactive principle to overcome the existing old antifungal drugs to treat opportunistic fungal diseases. This study is the first to report the in vitro antifungal efficacy of $\mathrm{C}$. axillaris.

\section{MATERIALS AND METHODS}

\section{Collection and processing}

Fresh whole plants of $C$. axillaris were harvested from the banana field in Pongumoodu, Thiruvananthapuram, Kerala, in the month of May and authenticated by the taxonomist Dr. D. Narasimhan, Centre for Floristic Research, Department of plant biology and biotechnology, Madras Christian College, Chennai. The herbarium specimen has been deposited in Loyola College, Chennai, India, with the voucher number of LCH 403. Plants were washed thoroughly and dried completely at room temperature under shade. Dried plants were ground into coarse powder using an electric blender and filtered through sieves. The powdered drug was stored in airtight container at ambient temperature for further use.

\section{Chemicals and reagents}

All solvents used for the extraction purpose were purchased from Merk, Germany. Chemicals and standard discs (fluconazole and clotrimazole) were procured from Himedia, Mumbai, India.

\section{Preparation of plant extracts}

Plant extracts were prepared by serial extraction method which involves successive extraction with solvents of increasing polarity from a low polar (Hexane) to high polar solvents (Ethyl acetate and Methanol) to ensure that a wide polarity range of compounds could be extracted. About $50 \mathrm{~g}$ of dried powder was soaked in $800 \mathrm{ml}$ hexane for $72 \mathrm{~h}$ with intermittent shaking at $120 \mathrm{rpm}$ in a shaker. The extract was filtered through Whatman No. 1 filter paper. The filtrate was dried completely to get a constant dry weight of the extract. The remaining plant residue from hexane extract was dried completely and soaked in $800 \mathrm{ml}$ of ethyl acetate and then methanol 
successively as above mentioned and the extracts were collected. The concentrated extracts were stored at $4{ }^{\circ} \mathrm{C}$ for further use.

\section{Fungal strains}

All the microbial cultures were obtained from Microbial Type Culture Collection and Gene Bank (MTCC), Institute of Microbial Technology (IMTECH), Chandigarh, India and Department of Microbiology, Christian Medical College, Vellore, Tamilnadu, India and National Chemical Laboratory (NCL), Pune, India. The fungal strains were Candida albicans (MTCC 227), Candida krusei, Candida tropicalis (MTCC 230), Microsporum gypsum, Malassezia pachydermatis, Trichophyton rubrum 57/01, Trichophyton mentagrophytes 66/01, Epidermophyton floccosum 73/01, Scopulariopsis sp. 101/01, Aspergillus flavus (MTCC-277), Botrytis cinerea and Curvularia lunata $46 / 0$. Fungal strains were stored at $4{ }^{\circ} \mathrm{C}$ in Sabouraud Dextrose slants.

\section{Inoculum preparation}

Fungal strains were subcultured in sabouraud dextrose agar (SDA) and incubated overnight at $37{ }^{\circ} \mathrm{C}$ for yeast, $3-7 \mathrm{~d}$ at $37{ }^{\circ} \mathrm{C}$ for Aspergillus species or $25^{\circ} \mathrm{C}$ for dermatophytes. Fungal spores were collected from the subculture and suspended into $5 \mathrm{ml}$ of sterile distilled water. The concentration of the spore suspension was adjusted to $10^{4} \mathrm{cfu} / \mathrm{ml}-\mathrm{using} 0.5 \%$ McFarland as standard. The spore suspension was further used to determine the antifungal assays such as disc diffusion and MIC.

\section{Antifungal activity by disc diffusion method}

Antifungal disc diffusion was performed according to standard procedure for yeast [16] and filamentous fungi [17]. The extract was dissolved in dimethyl sulfoxide (DMSO). $20 \mu \mathrm{l}$ of extract with 3 different concentrations ( $1.25 \mathrm{mg}, 2.5 \mathrm{mg}$ and $5 \mathrm{mg}$ ) were loaded in the disc and allowed to dry. The sterile Petri plates with SDA medium were swapped with fungal spore suspension. After drying the disc with extracts were placed on the Petri plates. The plates were kept inverted and incubated overnight at $37^{\circ} \mathrm{C}$ for yeast; $3-7 \mathrm{~d}$ at $37^{\circ} \mathrm{C}$ for Aspergillus species or $25^{\circ} \mathrm{C}$ for dermatophytes and zones formed were measured and tabulated. The experiment was performed in triplicates and mean values taken as the zone of inhibition which was expressed in millimetres $(\mathrm{mm})$. Fluconazole $(10 \mu \mathrm{g})$ and clotrimazole $(10 \mu \mathrm{g})$ were used as positive control. DMSO was used as negative control.

\section{Determination of antifungal activity by MIC}

The MIC was performed according to the standard procedure for yeast [18] and filamentous fungi [19]. The extracts were dissolved in DMSO. The microtitre plates were dispensed with $100 \mu \mathrm{l}$ of sabouraud dextrose broth (SDB). The initial concentration of extract was $1 \mathrm{mg} / \mathrm{ml}$ and it was serially diluted two-fold. $20 \mu \mathrm{l}$ of fungal spore suspensions were added to each well. Broth with fungal inoculum and DMSO was kept as negative control. Fluconazole and clotrimazole were used as positive control. The microtitre plates were sealed and incubated overnight at $37^{\circ} \mathrm{C}$ for yeast, 3-7 d at 37 ${ }^{\circ} \mathrm{C}$ for Aspergillus species or $25{ }^{\circ} \mathrm{C}$ for dermatophytes. After incubation, $40 \mu \mathrm{l}$ of $0.2 \mathrm{mg} / \mathrm{ml} \mathrm{P-iodonitrotetrazolium} \mathrm{(INT)} \mathrm{violet}$ was added to all the wells and incubated for half an hour to one hour to note the colour change. When there is any fungal growth, an electron from the living cell is transferred from NADH to INT violet and converted to formazan which gives rise to red colour. The lowest concentration in which red colour is not seen is taken as the MIC of the extract. The MIC values were expressed as $\mathrm{mg} / \mathrm{ml}$.

Table 1: Antifungal disc diffusion method of C. axillaris extracts

\begin{tabular}{|c|c|c|c|c|c|c|c|c|c|c|c|}
\hline \multirow[t]{3}{*}{ Fungi } & \multicolumn{11}{|c|}{ Zone of inhibition in $\mathrm{mm}$} \\
\hline & \multicolumn{3}{|c|}{ Hexane } & \multicolumn{3}{|c|}{ Ethyl acetate } & \multicolumn{3}{|c|}{ Methanol } & \multirow[b]{2}{*}{ Flu } & \multirow[b]{2}{*}{ Clot } \\
\hline & $\begin{array}{l}1.25 \\
\mathrm{mg} / \\
\text { disc }\end{array}$ & $\begin{array}{l}2.5 \\
\mathrm{mg} / \\
\text { disc }\end{array}$ & $\begin{array}{l}5 \\
\text { mg/ } \\
\text { disc }\end{array}$ & $\begin{array}{l}1.25 \\
\mathrm{mg} / \mathrm{disc}\end{array}$ & $\begin{array}{l}2.5 \\
\mathrm{mg} / \\
\text { disc }\end{array}$ & $\begin{array}{l}5 \\
\text { mg/ } \\
\text { disc }\end{array}$ & $\begin{array}{l}1.25 \\
\mathrm{mg} / \\
\text { disc }\end{array}$ & $\begin{array}{l}2.5 \\
\mathrm{mg} / \\
\text { disc }\end{array}$ & $\begin{array}{l}5 \\
\text { mg/ } \\
\text { Disc }\end{array}$ & & \\
\hline $\mathrm{F}_{1}$ & 15 & 20 & 21 & 21 & 23 & 25 & 15 & 16 & 19 & - & 14 \\
\hline $\mathrm{F}_{2}$ & 14 & 18 & 31 & 14 & 20 & 32 & 11 & 13 & 22 & - & 10 \\
\hline $\mathrm{F}_{3}$ & 8 & 10 & 12 & 11 & 14 & 18 & 9 & 12 & 14 & - & 11 \\
\hline $\mathrm{F}_{4}$ & - & - & - & 7 & 8 & 13 & 7 & 8 & 9 & - & 9 \\
\hline $\mathrm{F}_{5}$ & 10 & 17 & 25 & 17 & 23 & 35 & 10 & 15 & 20 & - & 14 \\
\hline $\mathrm{F}_{6}$ & - & - & 8 & 8 & 8 & 11 & - & - & - & - & 12 \\
\hline $\mathrm{F}_{7}$ & 11 & 19 & 28 & 23 & 30 & 35 & 13 & 21 & 24 & - & 15 \\
\hline $\mathrm{F}_{8}$ & - & - & - & 10 & 11 & 13 & - & - & - & - & 14 \\
\hline $\mathrm{F}_{9}$ & 9 & 15 & 26 & 24 & 29 & 34 & 14 & 20 & 27 & - & - \\
\hline $\mathrm{F}_{10}$ & 11 & 18 & 24 & 9 & 12 & 21 & 24 & 29 & 35 & - & 11 \\
\hline $\mathrm{F}_{11}$ & 18 & 22 & 27 & 24 & 31 & 35 & 23 & 31 & 36 & - & 13 \\
\hline$F_{12}$ & 12 & 12 & 17 & 19 & 21 & 27 & 9 & 12 & 24 & - & 13 \\
\hline
\end{tabular}

Note: $\mathrm{F}_{1}-$ C. albicans; $\mathrm{F}_{2}-$ C. krusei; $\mathrm{F}_{3}-$ C. tropicalis; $\mathrm{F}_{4}-$ M. gypseum; $\mathrm{F}_{5}-$ M. pachydermatis; $\mathrm{F}_{6}-$ T. rubrum; $\mathrm{F}_{7}-T$. mentagrophytes; $\mathrm{F}_{8}-\mathrm{E}_{\text {. floccosum; }} \mathrm{F}_{9}-$ Scopulariopsis sp.; $\mathrm{F}_{10}-$ A. flavus; $\mathrm{F}_{11}-$ B. cinerea; $\mathrm{F}_{12}-$ C. lunata; nt: not tested; (-) no activity; Flu-Fluconazole; Clot-Clotrimazole.

Table 2: MIC values of $C$. axillaris extracts

\begin{tabular}{|c|c|c|c|c|c|}
\hline Fungi & Hexane $(\mu \mathrm{g} / \mathrm{ml})$ & Ethyl acetate $(\mu \mathrm{g} / \mathrm{ml})$ & Methanol $(\mu \mathrm{g} / \mathrm{ml})$ & Fluconazole $(\mu \mathrm{g} / \mathrm{ml})$ & Clotrimazole $(\mu \mathrm{g} / \mathrm{ml})$ \\
\hline$F_{1}$ & 125 & 62.5 & 125 & 125 & $<31.625$ \\
\hline $\mathrm{F}_{2}$ & 62.5 & 62.5 & 125 & 125 & 31.625 \\
\hline $\mathrm{F}_{3}$ & 250 & 125 & 250 & 125 & 31.625 \\
\hline $\mathrm{F}_{4}$ & nt & $\mathrm{Nt}$ & nt & 125 & 62.5 \\
\hline $\mathrm{F}_{5}$ & 125 & 62.5 & 250 & 125 & $<31.625$ \\
\hline $\mathrm{F}_{6}$ & nt & $\mathrm{Nt}$ & nt & 125 & $<31.625$ \\
\hline $\mathrm{F}_{7}$ & 62.5 & 31.25 & 125 & 125 & $<31.625$ \\
\hline $\mathrm{F}_{8}$ & nt & $\mathrm{Nt}$ & nt & 125 & $<31.625$ \\
\hline $\mathrm{F}_{9}$ & 125 & 31.625 & 125 & 125 & 125 \\
\hline $\mathrm{F}_{10}$ & 125 & 125 & 62.5 & 62.5 & 31.625 \\
\hline$F_{11}$ & 62.5 & 31.625 & 31.625 & 125 & $<31.625$ \\
\hline $\mathrm{F}_{12}$ & 125 & 62.5 & 125 & 125 & $<31.625$ \\
\hline
\end{tabular}

Note: $\mathrm{F}_{1}-$ C. albicans; $\mathrm{F}_{2}-$ C. krusei; $\mathrm{F}_{3}-$ C. tropicalis; $\mathrm{F}_{4}-$ M. gypseum; $\mathrm{F}_{5}-$ M. pachydermatis; $\mathrm{F}_{6}-$ T. rubrum; $\mathrm{F}_{7}-T$. mentagrophytes; $\mathrm{F}_{8}-\mathrm{E}_{\text {. floccosum; }} \mathrm{F}_{9}-$ Scopulariopsis sp.; $\mathrm{F}_{10}-$ A. flavus; $\mathrm{F}_{11}-$ B. cinerea; $\mathrm{F}_{12}-\mathrm{C}$. lunata; nt: not tested. 


\section{RESULTS}

\section{Disc diffusion method}

In antifungal disc diffusion method, $C$. axillaris showed high antifungal activity by forming a zone of inhibition up to $36 \mathrm{~mm}$ at high concentration $(5 \mathrm{mg} / \mathrm{ml})$. The antifungal efficiency of the hexane, ethyl acetate and methanol extracts of $C$. axillaris by disc diffusion method was summarised in table 1.

\section{Determination of MIC}

After the incubation with INT, the appearance of pink colour was observed in wells which had living fungal cells and well which appeared colourless was indicated the inhibition of fungal growth by the extract of $C$. axillaris. The MIC values of $C$. axillaris tabulated in table 2. It showed a wide range of MIC values from 0.25-0.031 $\mathrm{mg} / \mathrm{ml}$. Ethyl acetate extract showed high MIC values for many tested fungi.

\section{DISCUSSION}

Worldwide fungal diseases are one of the main causes of morbidity and mortality [20]. Recent years the fungal infections in human have dramatically increased from superficial to disseminate or deeply invasive due to the increasing immunocompromised population with cancer, organ transplantation, HIV infection, and individuals receiving immunosuppressive treatments. The prolonged immunosuppression with more intensive regimens causes invasive fungal infections in patients undergoing transplants or treatment for malignancies [21]. In the present study, we have investigated 5 yeasts and 7 filamentous fungi which cause various infections in immunocompromised people. In immunocompromised patients, Candida sp. cause invasive candidiasis and attribute $77 \%$ death [22]. T. rubrum, T. mentagrophytes, E. floccosum, M. gypseum cause dermatophytosis in immunocompromised patients [23]. In immunocompromised patients, M. pachydermatis cause invasive infections and Scopulariopsis sp. causes invasive sinusitis [24 and 25]. A. flavus cause aspergillosis, otitis, keratiti, pulmonary and systemic infections in immunocompromised patients [26]. C. lunata is most common in immunocompromised people and causes keratitis [27].

In our present study for the first time, the antifungal activity of $C$. axillaris was investigated. Even though plants from Commelinaceae family were investigated for its antimicrobial activity, there are very fewer investigations have been made to prove their antifungal efficacy. The ethanol extracts of $C$. benghalensis from Commelinaceae family exhibited high antifungal activity than the standard drug at the minimum concentration [28]. C. axillaris showed high antifungal activity against the tested fungal strains. The highest antifungal activity was recorded for ethyl acetate extract against $T$. mentagrophytes, Scopulariopsis sp., B. cinerea and methanol extract against $B$. cinerea. It inhibited the growth in its low dose 0.031 $\mathrm{mg} / \mathrm{ml}$ ). The hexane extract of $C$. axillaris showed high antifungal activity against $C$. krusei, T. mentagrophytes, $B$. cinerea and moderate activity against C. albicans, C. tropicalis, M. pachydermatis, Scopulariopsis sp., A. flavus and C. lunata. The hexane, ethyl acetate and methanol extracts of $C$. axillaris were inactive against $M$. gypseum, T. rubrum and E. floccosum. In this current study, we used two commercial azoles such as fluconazole and clotrimazole which are used to treat infections caused by fungal strains in immunocompromised patients. Fluconazole is a triazole and clotrimazole is an imidazole, are used to treat antifungal infections such as thrush, candidiasis, funguria, ear infections, skin infections, urinary infections and various fungal infections in AIDS patients, bone marrow transplant recipients and leukemia patients [29-36]. Extracts of $C$. axillaris showed superior activity than fluconazole. Clotrimazole showed sensitivity towards the tested fungal strains. Among these 3 extracts (hexane, ethyl acetate and methanol) of $C$. axillaris, the ethyl acetate extract showed the highest antifungal activity against C. albicans, C. krusei, M. pachydermatis, T. mentagrophytes, Scopulariopsis sp., B. cinerea and C. lunata. It exhibited the strongest and most potential antifungal activity than hexane and methanol extracts. Tamokou et al. studied the antifungal activity of ethyl acetate extract of Albizia adianthifolia and isolated compounds with antifungal activity [37]. The ethyl acetate fraction of Garcinia mangostana-Linn pericarp extract showed antifungal activity against candida albicans [38]. Bisht et al. proved the antifungal activity of banana leaf ethyl acetate extract against $P$. oxalicum [39]. These works support our study, that the ethyl acetate extract of plants can have antifungal principals. Hence this study proved that the ethyl acetate extract of $C$. axillaris poses more active and potential antifungal compounds that can fight against opportunistic fungal diseases.

\section{CONCLUSION}

From the present study, it is clear that the ethyl acetate extract of $C$. axillaris has great potential antifungal principles. Since ethyl acetate extract showed better activity than the commercially used drug (fluconazole) for fungal infections, it is clear that they should poses active principles with high antifungal activity as well as with better efficacy to replace the older drugs to fight against updating MDR fungal strains. The antifungal activity may be due to the single compound or a synergetic effect of multiple compounds. Phytochemical evaluation and isolation of compounds responsible for its antifungal activity are needed to establish a high potential antifungal drug that can fight against the opportunistic and multidrug resistance fungal strains.

\section{AUTHOR CONTRIBUTION}

Conception and design of this study, acquisition of data, analysis, interpretation of data and drafting the manuscript was done by the first author (Anto Suganya Regis). Conception of the study, revising the manuscript critically for important intellectual content was performed by the corresponding author (Jeya Jothi Gabriel).

\section{CONFLICT OF INTERESTS}

Declared none

\section{REFERENCES}

1. Krasner RI. Concepts of microbial disease. In: The Microbial Challenge: Human-Microbe Interactions. Emerging Infect Dis 2002;6:103-12.

2. Park BJ, Wannemuehler KA, Marston BJ, Govender N, Pappas PG, Chiller TM. Estimation of the current global burden of cryptococcal meningitis among persons living with HIV/AIDS. AIDS 2009;23:525-30.

3. Upadhyay MP, Karmacharya PC, Koirala S, Tuladhar NR, Bryan LE, Smolin G, et al. Epidemiological characteristics, predisposing factors, and etiologic diagnosis of corneal ulceration in Nepal. Am J Ophthalmol 1991;111:92-9.

4. Matee MI, Scheutz F, Moshy J. Occurrence of oral lesions in relation to clinical and immunological status among HIVinfected adult Tanzanians. Oral Dis 2000;6:106-11.

5. Chen J, Yang Q, Huang J, Li L. Risk factors for invasive pulmonary aspergillosis and hospital mortality in acute-onchronic liver failure patients: a retrospective cohort study. Int J Med Sci 2013;10:1625-31.

6. Smith N, Denning DW. Underlying pulmonary disease frequency in patients with chronic pulmonary aspergillosis. Eur Resp J 2011;37:865-72.

7. Denning DW, Pleuvry A, Cole DC. Global burden of chronic pulmonary aspergillosis complicating sarcoidosis. Eur Resp J 2013;41:621-6.

8. JH Rex, MG Rinaldi, MA Pfaller. Resistance of candida species to fluconazole. Antimicrob Agents Chemother 1995;39:1-8.

9. Ruhnke M, Eigler A, Tennagen I, Geiseler B, Engelmann E, Trautmann M. Emergence of fluconazole-resistant strains of Candida albicans in patients with recurrent oropharyngeal candidosis and human immunodeficiency virus infection. J Clin Microbiol 1994;32:2092-8.

10. Saliba F, Dupont B. Renal impairment and amphotericin B formulations in patients with invasive fungal infections. Med Mycol 2008;46:97-112.

11. Bruggemann RJM, Alffenaar JWC, Blijlevens NMA, Billaud EM, Kosterink JGW, Verweij PW, et al. Clinical relevance of the pharmacokinetic interactions of azole antifungal drugs with other coadministered agents. Clin Infect Dis 2009;48:1441-58. 
12. Ahmad SR, Singer SJ, Leissa BG. Congestive heart failure associated with itraconazole. Lancet 2001;357:1766-7.

13. Riahi RR, Cohen PR. Voriconazole-associated phototoxicity [letter]. Dermatol Online J 2011;17:15.

14. Morice C, Acher A, Soufir N, Michel M, Comoz F, Leroy D, et al. Multifocal aggressive squamous cell carcinomas induced by prolonged voriconazole therapy: a case report. Case Report Med 2010. Doi:10.1155/2010/351084

15. Cook CDK. Aquatic and wetland plants of India. New York: Oxford University press Inc; 1996.

16. CLSI. Method for Antifungal Disk Diffusion Susceptibility Testing of Yeasts; Approved Guideline. 2 ${ }^{\text {nd }}$ Edition. CLSI document M44-A2. Wayne PA. Clinical and Laboratory Standards Institute; 2009.

17. CLSI. Method for Antifungal Disk Diffusion Susceptibility Testing of Nondermatophyte Filamentous Fungi; Approved Guideline. CLSI document M51-A. Wayne PA. Clinical and Laboratory Standards Institute; 2010.

18. Clinical and Laboratory Standards Institute. Reference method for broth dilution antifungal susceptibility testing of yeasts; Approved standard-third edition; CLSI document M27-A3. Clinical and Laboratory Standards Institute, Wayne; 2008a.

19. Clinical and Laboratory Standards Institute. Reference method for broth dilution antifungal susceptibility testing of filamentous fungi; approved standard CLSI document M38-A2. Clinical and Laboratory Standards Institute, Wayne; 2008b.

20. Council of Scientific and Industrial Research. Wealth of India, publications and information directory. New Delhi, India: CSIR 1998. p. 164.

21. Fortes TO, Alviano DS, Tupinamba G, Padron TS, Antoniolli AR, Alviano CS, et al. Production of an antimicrobial substance against Cryptococcus neoformans by Paenibacillus brasilensis Sa3 isolated from the rhizosphere of Kalanchoe brasiliensis. Microbiol Res 2008;163:200-7.

22. Trick WE, Fridkin SK, Edwards JR, Hajjeh RA, Gaynes RP. Secular trend of hospital-acquired candidemia among intensive care unit patients in the United States during 1989-1999. Clin Infect Dis 2002;35:627-30.

23. Public Health Agency of Canada (PHAC). Pathogen Safety Data Sheet-Epidermophyton floccosum, Microsporum spp. Trichophyton spp. Pathogen Regulation Directorate, PHAC. Available from: http://www.phac-aspc.gc.ca/lab-bio/res/psdsftss/epidermophyton-eng.php. [Last accessed on 02 Mar 2017]

24. Amend A. From dandruff to deep-sea vents: Malassezia-like fungi are ecologically hyper-diverse. PLOS Pathog 2014;10:1004277. Doi:10.1371/journal.ppat.1004277

25. Analssie EJ, Bodey GP, Kantarjian H, Ro J, Vartivarian SE, Hopfer R, et al. New spectrum of fungal infections in patient with cancer. Rev Infect Dis 1989;11:369-78.

26. Link HF. Observationes in ordines plantarum naturales. Dissertatio prima, complectens anandrarum ordines epiphytas, mucedines gastomycos et fungos der gesellschaft naturforschender freunde zu Berlin. Magazin für Die Neuesten Entdeckungen in Der Gesamten Naturkunde 1809;3:1-42.

27. Kaushik S, Ram J, Chakrabarty A, Dogra MR, Brar GS, Gupta A Curvularia lunata endophthalmitis with secondary keratitis. Am J Ophthalmol 2001;131:140-52.

28. Cuéllar C, Armando, Okori, Dennis O. Preliminary phytochemical and antimicrobial evaluation of the fresh and dried whole plant extracts from Commelina benghalensis. Rev Colombiana Cienc Anim 2010;2:104-16.

29. Sangeorzan JA, Bradley SF, He X, Zarins LT, Ridenour GL, Tiballi $\mathrm{RN}$, et al. Epidemiology of oral candidiasis in HIV-infected patients: colonization, infection, treatment, and emergence of fluconazole resistance. Am J Med 1994;97:339-46.

30. Koletar SL, Russell JA, Fass RJ, Plouffe JF. Comparison of oral fluconazole and clotrimazole troches as treatment for oral candidiasis in patients infected with human immunodeficiency virus. Antimicrob Agents Chemother 1990;34:2267-8.

31. Kauffinan CA, Bradley SF, Ross SC, Weber DR. Hepatosplenic candidiasis: successful treatment with fluconazole. Am J Med 1991;91:137-41.

32. Stern JC, Shah MK, Lucente FE. In vitro effectiveness of 13 agents in otomycosis and review of literature. Laryngoscope 1988;98:1173-7.

33. Fisher JF, Newman CL, Sobel JD. Yeast in the urine: solutions for a budding problem. Clin Infect Dis 1995;20:183-9.

34. Voss A, Meis JFGM, Korstanje JAAH. Fluconazole in the management of fungal urinary tract infections. Infection 1994:22:247-51.

35. Goodman JL, Winston DJ, Greenfield RA, Chandrasekar PH, Fox $\mathrm{B}$, Kaizer $\mathrm{H}$, et al. A controlled trial of fluconazole to prevent fungal infections in patients undergoing bone marrow transplantation. N Engl J Med 1992;326:845-51.

36. Winston DJ, Chandrasekar PH, Lazarus HM, Goodman JL, Silber $\mathrm{JL}$, Horowitz $\mathrm{H}$, et al. Fluconazole prophylaxis of fungal infections in patients with acute leukemia: results of a randomized placebo-controlled, double-blind, multicenter trial. Ann Intern Med 1993;118:495-503.

37. Tamokou JD, Mpetga DJS, Tene PKLM, Tane P, Kuiate JR Antioxidant and antimicrobial activities of ethyl acetate extract, fractions and compounds from stem bark of Albizia adianthifolia (Mimosoideae). BMC Complementary Altern Med 2012;12:99.

38. Rahmayanti F, Suniarti DF, Masúd ZA, Bachtiar BM, Wimardhani YS, Subita GP. Ethyl acetate fraction of Garcinia mangostana-linn pericarp extract: anti-Candida albicans and epithelial cytotoxicity. Asian J Pharm Clin Res 2016;9:357-60.

39. Bisht R, Chanyal S, Agrawal PK. Antimicrobial and phytochemical analysis of leaf extract of medicinal fruit plants. Asian J Pharm Clin Res 2016;9:131-6.

\section{How to cite this article}

- Anto Suganya Regis, Jeya Jothi Gabriel. Antifungal activity of Cyanotis axillaris (L.) D. don ex sweet against opportunistic fungal strains. Int J Pharm Pharm Sci 2017;9(7):140-143. 